\title{
The Use of Makassarese Language Based on Politeness Strategies: Review of the Universality of Yassi's Theoretical Framework
}

\author{
Nurjannah Syarifuddin, Abdul Hakim Yassi, Harlinah Sahib \\ Hasanuddin University, Indonesia
}

\begin{abstract}
The study is aimed to revisiting the politeness framework of Yassi's. The study discusses the factor that influenced someone in used politeness strategies of heritage language in South Sulawesi especially Makassarese language. The methodology of this research is used qualitative method. The data were observed randomly from native speakers of Makassarese in did communication. On Yassi's theoretical framework found there are six politeness strategies. The strategies are deference in non-kinship, deference in kinship intimacy in non-kinship, intimacy in kinship, hierarchy in nonkinship and hierarchy in kinship. Yassi's exposed that the ages is one of the important part in politeness. A positive politeness strategy is used when communicate with friends, usually used casual and direct speech. When communicate with the older used negative politeness. In this study the writer found there are eight strategies that influenced someone in used politeness strategy to complete Yassi's theory. The new strategy is educated in nonkinship and educated in kinship. This study found someone will respect if did communicate with the educated people even though they are younger or older also kinship or in kinship.
\end{abstract}

Keywords: Negative Politeness, Politeness Strategy; Positive Politeness

\section{INTRODUCTION}

$\mathrm{T}$ alking about communication and culture, Indonesia is rich of culture and ethnic groups in which each ethnic group has it is own vernacular language to communicate easily. Every vernacular language has it is own rule to arrange a proper conversation politely. One of regions in Indonesia, which has uniqueness especially in language, is South Sulawesi. In South Sulawesi, the people used some languages. Some of them are Makassarese, Buginese, and Torajanese. Language has a function to use for interacting with other people. (Idris et al., 2020).

Politeness is one of strategy that used to communicate. This politeness strategy is different in every region. Different language will be different rule in used politeness strategy. This article discussed the politeness strategy that used in Makassarese language. This article is revisiting the Yassi's politeness framework(1996). In this era the politeness framework of Yassi is still effective or need to be reformed. The variable in Yassi's politeness framework is the age, because the age is the dominant variable can affecting someone in used politeness strategies or not. The data were taken from some authors that research about politeness. The data related to Yassi's (1996). This dialogue will analyze by used the Yassi's theory.)

\section{REVIEW OF RELATED LITERATURE}

Every language it must be have their own politeness strategy. Politeness is the language that is used in polite way to communicate with each other. Usually politeness used when we are talking with the older person than us. Every language must have each own rule in used politeness strategies. It is interest to research because we may learned about the language that used in every country and every region, to avoid misunderstood between the users of languages, (Saleh, et al., 2021).

There are some theories about politeness. The theories are from Leech (1983), Brown et al. (1987), Holmes (2013), Scollon \& Scollon (1995), and the last is Yassi (1996). All the theories has it is own characteristic that different with each other. Leech (1983) found about politeness principle. In addition, he found that there are six maxims. Brown Levinson (1987) found positive and negative politeness on his theory. Holmes (2013) distinguished the positive and negative politeness (Brown Levinson theories) based on the gender of the user of language. Scollon \& Scollon (1995) found that the variable that determine the low value of variable $\mathrm{P}$ and the high value of the variable D $(-\mathrm{P},+\mathrm{D})$. The last is Yassi theory (1996) adapting B\&L's and S\&S's framework, developed politeness theoretical framework by introducing a new politeness system which has been empirically proven to be relatively more effective and compatible for heritage languages in Indonesia, see for instance Yassi 2011, 2012, 2016a,2016b and 2017. Yassi found politeness strategies into six types of social relation patterns governing politeness strategies employed by the participants in an interaction.

\section{Symetrical Relations}

1. Deference in non-kinship $(-\mathrm{P},+\mathrm{D},-\mathrm{K})$, example; interaction among strangers, they are known one another.

2. Deference in kinship $(-\mathrm{P},+\mathrm{D},+\mathrm{K})$, example; interaction among distant relatives.

3. Intimacy in non-kinship (-P,-D,-K), example; interaction among friends, colleagues, and close friends. 
4. Intimacy in kinship (-P,-D,+K), example; interaction among family members.

\section{Asymetrical Relations}

1. Hierarchy in non-kinship $(+\mathrm{P},+\mathrm{D},-\mathrm{K})$, example; interaction between super ordinate and subordinate, seniors and juniors.

2. Hierarchy in kinship $(+\mathrm{P},-\mathrm{D},+\mathrm{K})$, example; interaction between parents and children, uncle/aunt and nephew/niece, grandparents and grandchildren, and the likes.

According to Yassi(2018), he found that there are some politeness strategies that use in Makassar. Yassi's found six politeness strategies that had been adopted from Brown and Levinson (1978) \& Scollon \& Scollon (1995). The six strategies are deference in non-kinship, deference in kinship, intimacy in non-kinship, intimacy in kinship, hierarchy in non-kinship and hierarchy in kinship.

In this modern era education is one of the priorities that someone needed. Someone who has more intelligence will be respected in society. The society will be respected if someone has high educational level than her. In this case, the educational side is higher level than the age.

In Makassar especially, someone will be talked more politely if talked with the educational person than herself. Even though she is older than the educational person, she will used polite strategy. So according to that hypothesis, the writer found the other politeness strategies. The writer has been found the new politeness strategies. The two new politeness strategies will be complete the Yassi's theory.

\section{This Theory:}

1. Deference in non-kinship $(-\mathrm{P},+\mathrm{D},-\mathrm{K})$

2. Deference in kinship $(-\mathrm{P},+\mathrm{D},+\mathrm{K})$

3. Intimacy in non-kinship $(-\mathrm{P},-\mathrm{D},-\mathrm{K})$

4. Intimacy in kinship $(-\mathrm{P},-\mathrm{D},+\mathrm{K})$

5. Hierarchy in non-kinship $(+\mathrm{P},+\mathrm{D},-\mathrm{K})$

6. Hierarchy in kinship $(+\mathrm{P},-\mathrm{D},+\mathrm{K})$

7. Educated in non-kinship $(+\mathrm{P},+\mathrm{D},+\mathrm{K})$

8. Educated in kinship $(+\mathrm{P},+\mathrm{D},+\mathrm{K})$

\section{METHOD}

Methodology of this research is used qualitative method. According to Creswell and Poth (2016), they said that "qualitative is a process of understanding social or human problem in complex building, holistic picture, formed in verbal languages". In addition, In this research, language is an object of the research. The researcher observed the native speakers of Makassarese in used Makassarese language. The researcher observed randomly and used note taking to collect the data.

\section{FINDINGS AND DISCUSSION}

\section{Findings}

This part the researcher discussed about the finding of this research and discussed about the data.

After did a research and did analyze of the data, the researcher found the new strategies that used in Makassar. Beside six strategies that found by Yassi, the researcher found there are two other strategies that the native speakers of Makassarese used communicate. The strategies based on educational background. The two strategies are educated in non-kinship and educated in kinship. The two strategies included the communication around the member of family, friends, superior or junior and also the younger or the older person.

\section{Discussion}

Makassarese Language

\section{Deference in Non-kinship $(-P+D-K)$}

The two data in below, showed the politeness strategy nonkinship. The dialogue (a) between two persons that does not know each other (A: The buyer B: The seller). The second dialogue (b) between two people that meet for the first time (A: Speaker and B: Hearer)

Datum 1

Siapakatteanneballinasandalaka?

A: How you this price slipper

Jw much the price of this slipper?)

Punnaantutallumpulo lima sabbuhargana.

B: If that thirty thousand price

(That is price is thirty five thousand)

Datum 2

Tabe, erokaakkuta'nanganne, kiissengiballana dg bau

Excuse me will me ask this, you know

A: house dg. Bau

(Excuse me, I want to ask, do you now Dg. Bau's House?)

Dg bau? Njorengantuballanarirampi'namasijika.

B: Dg bau? There that house in beside mosque

(Dg. Bau? Her house beside the mosque)

According to dialogue above, the strategy that the speaker used is negative politeness strategy. Where, the speaker used that for the first time met with the hearer usually used politeness to show if the speaker is a kindness person. The 
speaker B used casual strategy when respond speaker A.

\section{Deference in Kinship $(-P+D+K)$}

These dialogue between two person in-kinship but they are the same age.

Datum 3

Tena nu cinikiammakku?

A: No. you see mother me.

(Don’t you see my Mom?)

Tena, angngapaika? Tenairiballa'nu?

B: No. Why

(No, what happened?)

Tenaja, iyotenairiballa

A: Nothing. yes no at home

(No matter, because she is not at home)

From the dialogue above, we can see the strategy that the speaker used is the same strategy. Both of used casual strategy when communicate. The speaker A and B used suffix - nu that means you but in impolite word. Beside that the speaker A responded the speaker B used the words Iyo that means yes, but in impolite words. The two speakers used the casual strategy because they are so closes with each other.

\section{Intimacy in Non-kinship (-P -D -K)}

These dialogues between two person non-kinship where is the speaker B older than speaker A.

\section{Datum 4}

Tettesiapanieroa'lamparikampusuka?

A: Time how you will goto campus

(What time you will go to campus?)

Tetteesalapangpi deh, kaerokkaangnganrerong. Kauiya?

B: Time nine Iwilleat first, you?

(At nine pm cause I will eat first. What about you?)

Iyye, tenatompa, siagangpekia'lampadeh

A: Yes. No alsowithmego

(Not yet, we will go together)

Erokkisenga'lampakemaeantu?

A: Will+you go where that

(Where will you go?)
Tenajajinne, ero'ja mange a'jampa-jampa

B: Nothing Jinne will I go walking

(Nothing Jinne, I just wanna go for refreshing)

Kemaebura'nennu?

A: Where husband+you

(Where is your husband?)

A'lampaikatteammekangsiagangaga-aganna

B: Go you fishingwithfriends

(He go for fishing with his friends)

From the dialogue above, the speaker A that older than speaker B used a casual strategy to communicate. We could see from the words that the speaker B used such as, Kau and suffix -nu that means you but in casual side. While the speaker A used negative politeness strategy to communicate with the speaker B.

\section{Intimacy in Kinship $(-P-D+K)$}

This dialogue between two person in-kinship, which is the speaker A is the little sister and the speaker B is the older sister.

Datum 5

Kak,sibukki?

A: Sister busy+you

(Sister, are you busy?)

Tenajandi, angngapai?

B: Nothing sister, why

(No, what happen?)

Niatugasku, natenakuissengi, gappakakulleki

A: There is task+me no me know maybe can + you

(I have an assignment, and I do not know it, can you help me)

Tugasapaka?

B: Task, what

(What task is it?)

Bahasainggriskak, tenakuissengibattuannaanne

A: Language English sister no me know meaning this

(English, Sister. I do not know what does it 
means)

Sinampe pi pale kubantuko, erokkarong a' je'ne

B:

\section{Later I help+youwill+me also water}

(Later I will help you, I will take bath first)

The dialogue above also showed politeness strategy. The speaker $\mathrm{A}$ as a little sister that used negative politeness strategy to communicated with his older sister. We could see form the words that used, such as, the used of suffix -ki. In south Sulawesi the used of suffix -ki means you in polite side and suffix -ko means you also but in impolite side.

\section{Hierarchy in Non-kinship $(+P+D-K)$}

This dialogue between two person non-kinship but they are in the same place or region. The speaker A is the older and the speaker B is the young.

Datum 6

Antekamma mi kulliahnu, le’bammi?

A:

How study+youfinish

(How is your study? Have done?)

Tenapakatte

B: Not yet you

(Not yet, sir)

Datum 7

Ngapanatena

numange

a'balanjaripasaraka?

A: Whyno you go buy in to Market

(Why you did not go to market?)

Le'ba'makattea'balanja, beru-beru

B: Have me you buy new

(I have already buy it)

Datum 8

Tena nu cinikiberkaskurimejayya?

A: Noyou see file +me on table

(Do not you see my file on the table?)

Tenakattepak

B: Noyou sir

(No sir)

The dialogue above showed the politeness strategy that the speaker B used. Because the speaker A is the older person, so the speaker B used a negative politeness strategy when did communication, while the speaker A used a casual strategy.

6. Hierarchy in Kinship $(+\mathrm{P}-\mathrm{D}+\mathrm{K})$

This dialogue between two person in-kinship which is the speaker A is the husband and Speaker B is the wife.

\section{Datum 9}

Mantang, nia tau akkio, assulukko be

A: Mantang there is people calling out $+y o u$

(Mantang, someone in outside, let you see there)

Tayangmidaeng, kubolikirongsassangku

B: Wait Daeng I save clothes+me

(Please wait daeng, I save my laundry first)

\section{Datum 10}

Tenakaantukullenica'ma-ca'ma?

A: No that can eat

(Is there any snack or cake?)

Kauantusangingero'nua'ca'ma

B: You that always will+you eating

(Why you always want to eat?)

Ngapamideeh, kacipuruki

A: Why hungry me

(I am hungry)

From the dialogue above there are two kinds strategy that the speaker B used. First is the used of positive politeness strategy when communicate with her husband. The second is casual strategy. The two dialogues are different in used of strategy, even though the participants are same. Because in south Sulawesi especially in Makassar the wife in a some situation will used a positive politeness strategy to her husband and the used of negative politeness strategy in a bad situation. Bad situation like when the wife is angry or bad mood, it will influence the used of casual strategy to her husband.

\section{Educated in non-kinship $(+P,+D,+K)$}

This dialogue between two persons that know each other but the first person has higher educational background than the second person.

1. B is higher educated than $A$ and $B$ is younger than $A$ 
Datum 11

Assikolaki'?

A: Study+you

(Are you studying?)

Iyye, tenapakatte

B: Yes, not yet you

(Not yet)

Ikkakulleja antuengpunnale'bakikuliata?

mange tugasnaerokipring.

A: Ikka can I goes to there ifdone+youstudy+you? There is assignment will print

(May I go to you if your study has been done?)

Nia kuliakukamma-

kammaanneanggennatangalloa, sinampepikuprin

B: There is study+my nowthis until noon, later I print

(I am studying now till the noon, later I will print it)

Chatma pale punnale'bamikipringi dii

A: Chat+me if have done+youprint (Please, chat me if you have to print it)

The dialogue above is between two persons that know each other but in kinship. The strategies that used are politeness strategy. A is older than B, but A used negative politeness strategy when talked with B. A used negative politeness strategy because B has a higher educational background than A. the other hand B also used negative politeness strategy. B used negative politeness strategy because B is older than A. So she needed to speak politely to A. Even though B has a higher educational background than $\mathrm{A}$, she known if we talked to the older person she need to use negative politeness strategy.

\section{2. $A$ is higher educated than $B$ and $A$ is older than $B$}

This dialogue is between two friends that work in the same place. The A is older than B and A also has higher educated than B.
Datum 12

Battukemaekiantu Pak?

A: Arrived where +you that Sir?

(Where have you been Sir?)

Battuaangngajara' anne $\mathrm{Bu}$

B: Arrived teached this Mis

(I had been teaching Mis)

Tettesiapasinampeningngajara Pak?

A: Hour how later you+teached Sir

(What time you will be teaching Sir?)

Tettese'repi Bu. Nia' rapa' sinampe Bu?

B: Hour one Mis. There is meeting later

Mis?

(At one PM Mis. Is there any meeting?)

Iyye Pak nia' tettesampulo

A: Yes Sir there is hour ten

Yes Sir, at ten AM

Datum 13

Battukemaekiantu Pak?

A: Arrived where+you that Sir?

(Where have you been Sir?)

Battuaangngajara' anne $\mathrm{Bu}$

B: Arrived teached this Mis

(I had been teaching Mis)

Tettesiapasinampeningngajara Pak?

A: Hour how later you+teached Sir

(What time you will be teaching Sir?)

Tettese'repi Bu. Nia' rapa' sinampe Bu?

B: Hour one Mis. There is meeting later Mis?

(At one PM Mis. Is there any meeting?)

Iyye Pak nia' tettesampulo

A: Yes Sir there is hour ten

(Yes Sir, at ten AM)

All the speakers on the dialogue above used politeness strategy. Even though $\mathrm{A}$ is older than $\mathrm{B}$, she still used negative politeness to $\mathrm{B}$. $\mathrm{B}$ also used negative politeness to A, cause he is younger than A. 
3. This dialogue between two friends in the same class. Speaker A and B is the same level of educational background.

\section{Datum 14}

\section{Erokkiamminawangkelas TOEFL?}

A: Will+you join class TOEFL?

(Will you join in TOEFL class?)

Siagangkinai?

B: With whom?

(With whom is the class?)

Siagangjekiagang-agangkelasta

A: With friends class + our

(With our classmates)

$\mathrm{Oh}$, ping siapamianjopertemuanga?

B: Oh, how that meeting?

(Oh, how many meeting have done?)

Tenaja, nakkenampaitompasikaliamminawang

A: Nothing, I knew also one join

(Nothing, I just one time joined that class)

Iyye pale, ero'jaamminawang

B: Yes, will+I join

(Yes, I will join)

8. Educated in kinship $(+P,+D,+K)$

In this part there are three dialogues. These dialogue between two persons in kinship, but the one has a higher educated than the other one.

1. The dialogue between two cousins. Speaker A is younger than speaker B and speaker A has higher educated than B.

Datum 15

Battukisengrikampuska?

B: Arrive+youat+campus?

(Have you been to campus?)

Iyye, niaurusangkukatte

A: Yes, there is affair you

(Yes, I have some affairs)

Maekirongangnganre pale

B: Let+you eat

(Let you eat first)
Sinampe pi katte, bassoro' inja

A: Later you, full I

(Later, I am still full)

The dialogue above used politeness strategy. Usually when someone talked with younger person than herself, she will used casual form. But the dialogue above the speaker B used negative politeness. The speaker A also used negative politeness. From the dialogue above, it does not matter if you are younger than someone. If you are educated person, you will be respected by the others people.

2. This dialogue between grandchild (A) and the cousin of his grandmother (B). The grandchild had been finished his degree.

\section{Datum 16}

Antekammakabarattaamma?

A: How news grandmother

(How are you grandma?)

Bajik-bajikjianak, sallonasengnampabattu

$\mathrm{B}$. Fine child long new come

(I am good, it had been a long time you come)

Iyyeamma, nampaiselesaikuliahku

A: Yes grandmother, had been study+my

(Yes grandma, my study had been finished)

Anjamamekikahnak?

B: Work you child?

(Do you work now?)

Nampaiaero' wawancaraanneamma

A: New will interview this grandmother

(Later I will interview grandma)

Nakku' kurikatteanak

B: Miss I to+you child

(I miss you)

Iyyeamma, kanampaianneniawattuku

A: Yes grandmother newthis there is time +my

(Yes grandma, I just have a time)

The dialogue above used politeness strategy. Both of the speakers used negative politeness. Even though the speaker B is older than speaker A, she still used negative politeness. It because the speaker A is educated person so someone will 
respect with him included his family.

\section{CONCLUSION}

Politeness is one of the most important things that someone needs to know before doing communication. Especially in South Celebes, there are some rule that someone need to know when communicate. According to the data that has been explained, there are some factors that influence the politeness strategy in doing communication. The age is the first factors that influence someone to used negative politeness strategy. Whatever they are known each other or does not know each other, they are superiors or subordinates, and they senior or junior if they are older than the speaker so the speaker will used the politeness strategy. The second factors are the status in a family. Usually the wife will used politeness strategy when talk with their husband. The other side also a mother will used politeness strategy when communicate with her children to educate the children to always be kindness one and have a good attitude and behavior. They will use negative politeness when talked with you.Based on the explanation above, the researchers concluded that 1). Accroding to the Yassi's framework, the researcher reveals that sellers use their local language when interacting with customers who have difficulty understanding the seller's objectives. 2). The seller employs local language in response to market situations and conditions. Customers are classified according to their age, job level, and educational background. When the seller is getting hard to explain to the customer in Indonesian, the sellers will use their local language to make the customers understand easily.

\section{REFERENCES}

[1]. Brown, P., \& Levinson, S. C. (1978). Universals in language Usage: Politeness Phenomena. In Questions and Politeness: Strategies in social interaction (pp. 56-311). Cambridge University Press.

[2]. Brown, P., Levinson, S. C., \& Levinson, S. C. (1987). Politeness: Some Universals in Language Usage (Vol. 4). Cambridge
University Press.

[3]. Creswell, J. W., \&Poth, C. N. (2016). Qualitative Inquiry and Research Design: Choosing AmongFiveApproaches. Sage Publications.

[4]. Holmes, J. (2013). Women, Men and Politeness. Routledge.

[5]. Idris, A. M. S., Adliah, A., \& Alfina, S. (2020).Multilingual Interaction in Classroom Context. Eternal (English, Teaching, Learning, and Research Journal), 6(2), 381. https://doi.org/10.24252/Eternal.V62.2020.A13.

[6]. Leech, G. N. (1983). Principles of Pragmatics London: Longman Group Ltd.

[7]. Saleh, N. J., Yassi, A. H., \& Rahman, F. (2021). Strategy of Apology in Buginese: A Sociolinguistic Study. ELS Journal on Interdisciplinary Studies in Humanities, 4(2)188-196.

[8]. Scollon, R.,Scollon,S.B.K. (1995). Intercultural Communication: A DiscourseApproach (Oxford, Cambridge: Blackwell.

[9]. Yassi, A. H. (1996). Negating and affirming a proposition in Makassarese: A cross-cultural communication study. Unpublished Master Research Paper. Department of Linguistics, The University ofSydney, NSW. Australia.

[10]. Yassi, A. H. (2016). Model kerangkateorikesantunan yang efektifmengkajipolakesantunanbahasa-bahasa di Indonesia: Mempertanyakankeuniversalitasankerangkateorikesantunan Brown \&Levinson. In Prosiding Seminar AntarBangsa (ASBAM.) ke-5. Hal (pp. 19-28).

[11]. Yassi, A. H. (2016a). Model kerangkateorikesantunan yang efektifmengkajipolakesantunanbahasa-bahasa di Indonesia: Mempertanyakankeuniversalitasankerangkateorikesantunan Brown \& Levinson. In Prosiding Seminar AntarBangsa (ASBAM.) ke-5. Hal (pp. 19-28).

[12]. Yassi, A. H. Pemetaanpolasistemkesantunanbudayabahasa-bahasa Sulawesi Selatan dan Barat (Sulselbar): Harmonisasikehidupansosialbertetangga. In Prosiding Seminar NasionalBulanBahasaFakultasIlmuBudayaUniversitasHasanuddi $n$ (pp. 11-12).

[13]. Yassi, A. H. (2017). Ancangan model kerangkateorikesantunan yang efektifmengkajibudayabahasa-bahasa heritage di Asia: Review terhadapkeuniversalitasankerangkateorikesantunan Brown \& Levinson. Linguistik Indonesia, 35(2), 159-186.

[14]. Yassi, A. H. (2018). Mapping the Politeness Systems of Heritage Language Culture of South Sulawesi, Indonesia: Ages and Politeness Strategies. In The 2nd International Conference on Culture, Art, Language, and Literature in Digital Humanities: Academic and Creative Challenges (pp. 1-16). 